WSZELACZYŃSKA, E; SZCZEPANEK, M; POBEREŻNY, J; KAZULA, MJ. 2019. Effect of biostimulant application and long-term storage on the nutritional value of carrot. Horticultura Brasileira 37: 451-457.DOI - http://dx.doi.org/10.1590/S0102-053620190414

\title{
Effect of biostimulant application and long-term storage on the nutritional value of carrot
}

\author{
Elżbieta Wszelaczyńska ${ }^{1 \mathbb{D}}$; Małgorzata Szczepanek ${ }^{1 \mathbb{D}}$; Jarosław Pobereżny ${ }^{1 * \mathbb{D} ;}$ Maciej J Kazula ${ }^{2} \mathbb{D}$
}

${ }^{1}$ Faculty of Agriculture and Biotechnology, University of Science and Technology, Bydgoszcz, Poland; ${ }^{2}$ Department of Agronomy and Plant Genetics, University of Minnesota, Minnesota, USA; poberezny@utp.edu.pl (*corresponding author)

\begin{abstract}
The nutritional value of carrot is determined by the content of total sugars and monosaccharides, carotenoids and vitamins, including vitamin C, in its roots. In 2009-2011, field experiments were carried out concerning the effect of biostimulating preparations applied during the carrot vegetation period on selected nutrients of its roots (total sugars, monosaccharides, carotenoids and vitamin C). Two biostimulants were foliarly applied in doses of 2 or $3 \mathrm{~L} \mathrm{ha}^{-1}$ on various dates. Kelpak SL and Asahi SL: one, two or three applications; where, second and third applied at 2-week interval, additionally Kelpak SL: one application at 4-leaf phase, followed by additional application after 4 weeks. The field study was conducted in a randomized block design with four replications. The treatments of plant protection from diseases and pests complied with carrot requirements. The subject of the research was carrot of the Karotan cultivar. The content of selected components in carrot roots was determined directly after harvest and after six months of storage in the storage chamber with controlled temperature and relative air humidity. The foliar application of Kelpak SL in a single dose $\left(2 \mathrm{~L} \mathrm{ha}^{-1}\right)$ at 4-leaf development phase resulted in the significant increase of total sugars, reducing sugars, total carotenoids and vitamin C. A six-month storage period resulted in a decrease of total sugars by $5 \%$ and ascorbic acid by $16.8 \%$ compared to nutritional values measured right after harvest.
\end{abstract}

Keywords: Daucus carota, Ecklonia maxima, seaweed, carotenoids, vitamin $\mathrm{C}$.

\section{RESUMO}

Efeito da aplicação de bioestimulante e armazenamento a longo prazo no valor nutricional da cenoura

O valor nutricional da cenoura é determinado pelo teor de açúcares totais e monossacarídeos, carotenóides e vitaminas, incluindo vitamina C, em suas raízes. Em 2009-2011, foram realizadas pesquisas de campo visando o efeito de preparações bioestimulantes, aplicadas durante o período vegetativo da cenoura, sobre os nutrientes selecionados de suas raízes (açúcares totais, monossacarídeos, carotenóides e vitamina $\mathrm{C}$ ). Dois bioestimulantes foram aplicados foliarmente em doses de 2 ou $3 \mathrm{~L} \mathrm{ha}^{-1}$ em várias datas: Kelpak SL e Asahi SL. Asahi SL foi aplicado uma, duas ou três vezes; a segunda e terceira aplicação foram em intervalo de 2 semanas. Kelpak SL foi testado em uma aplicação na fase de 4 folhas, seguida de aplicação adicional após 4 semanas. $O$ estudo de campo foi realizado em delineamento de blocos casualizados com quatro repetições. Os tratamentos de proteção de plantas contra doenças e pragas atenderam aos requisitos da cenoura, cultivar Karotan. O teor de componentes selecionados nas raízes de cenoura foi determinado diretamente após a colheita e após seis meses de armazenamento em câmara de armazenamento com temperatura controlada e umidade relativa do ar. A aplicação foliar de Kelpak SL em dose única $\left(2 \mathrm{~L} \mathrm{ha}^{-1}\right)$ na fase de desenvolvimento da planta com 4 folhas, resultou em aumento significativo de açúcares totais, açúcares redutores, carotenóides totais e vitamina $\mathrm{C}$. $\mathrm{O}$ armazenamento por seis meses resultou em diminuição de açúcares totais em $5 \%$ e de ácido ascórbico em 16,8\%, comparado com os valores nutricionais medidos imediatamente após a colheita.

Palavras-chave: Daucus carota, Ecklonia maxima, algas marinhas, carotenoides, vitamina $\mathrm{C}$.

Received on April 9, 2019; accepted on November 1, 2019

$\mathrm{C}$ Carrot (Daucus carota) is one of the main vegetables cultivated in moderate climate regions. Although most carrot crops supply the Polish market, a large scale of its production and growing demand resulted in the fact that it has also become a significant export commodity (Sękara et al., 2012).

Because of its high nutritional value, culinary suitability, broad processing possibilities and year-round availability, carrot is used primarily for direct consumption and secondly as raw material in food and industry processing. Raw carrot is an important source of human nutritional diet, being that of a total $52 \mathrm{~kg}$ of vegetables consumed on a yearly basis per person in Poland, carrot itself contributes $8.5 \mathrm{~kg}$ (Central Statistical Office, 2016). Content of carotenoids, sugars, vitamins, minerals and fibre are important in determining carrot root nutritional value (Kiraci \& Padem, 2016).

Global trends related to the production of organic food and protection of natural environment resulted in a growing interest in vegetable cultivation technologies involving stimulation of growth and 
quality through foliar fertilization with macro- and micronutrients, biostimulating preparations, microbial inoculants, algae extracts, effective microorganisms, preparations or soil fertilizers (Kwiatkowski et al., 2013). Generally the role of biostimulants is to improve the condition of plants regarding sensitivity to stress related to unfavourable environmental conditions and support for defence mechanisms against diseases and pests. Additionally, biostimulants can contribute to an increase of nutrients availability in the soil and to intensify water and nutrients uptake through the plant root system (Kocira et al., 2018). However, the effectiveness of biostimulating products on vegetables highly depends on the application rate and frequency (Alam et al., 2014; Szczepanek et al., 2017). Biostimulants can be natural or artificial. Among popular natural biostimulants are seaweed extracts, which can be produced from sea algae. Commercial product such as Kelpak SL, made of Ecklonia maxima, contains phytohormones (auxins, cytokinins), alginate, amino acids, as well as small amounts of macro- and micronutrients (Szczepanek \& SiwikZiomek, 2019). Another important group on biostimulants are artificially manufactured based on nitrophenolsderivatives group compounds. Among them, products such as Asahi SL has been proven to increase content of chlorophyll in leaves, intensifying photosynthesis, but also supported plant growth and development and counteracted rapid plant aging (Czeczko \& Mikos-Bielak, 2004).

The quality of carrot roots depends on cultivar genetic features, environmental conditions during growing season and final storage, as well as all agro-technical decisions made by the growers designed to protect and enhance crop production. The introduction of biostimulants to modern production technologies of various plant species (Alam et al., 2014) provided a direct inspiration to undertake study on determining the optimum dose of biostimulant application in carrot cultivation which is not well understood. Therefore, this study was conducted to evaluate the effect of biostimulating products on the nutritional value of carrot roots measured at harvest and after the longterm storage.

\section{MATERIAL AND METHODS}

The research material has come from field experiments performed at the Research Station in Mochełek $\left(53^{\circ} 13^{\prime} \mathrm{N} ; 17^{\circ} 51^{\prime} \mathrm{E}\right)$, in the years 2009 2011. The field experiment was carried out on light soil with a medium content of available phosphorus $190-210 \mathrm{mg}$ $\mathrm{kg}^{-1}$ and potassium $95-150 \mathrm{mg} \mathrm{kg}^{-1}$ (both determined with the EgnerRiehm method), a very low content of magnesium $<20.0 \mathrm{mg} \mathrm{kg}^{-1}$ (Schetschabel method) and slightly acid reaction $(\mathrm{pH}$ in 1M KCL 5.7-6.1) (measured by potentiometry). The content of organic carbon (7.55-7.80 $\mathrm{g} \mathrm{kg} \mathrm{g}^{-1}$ of soil) and total nitrogen (0.69-0.75 $\mathrm{g} \mathrm{kg}^{-1}$ of soil) was relatively low.

The experiment design was a singlefactor randomized block with four replications. The research involved the use of mid-late Karotan carrot cultivar. The experiment covered the following treatments:1) control; 2) Kelpak SL at 4-leaf stage, $3 \mathrm{~L} \mathrm{ha}^{-1}$; 3) Kelpak SL at 4-leaf stage $2 \mathrm{~L} \mathrm{ha}^{-1}$; 4) Kelpak SL at 4-leaf stage $3 \mathrm{~L} \mathrm{ha}^{-1}+$ after 14 days 2 $\mathrm{L} \mathrm{ha}^{-1}$; 5) Kelpak SL at 4-leaf stage $2 \mathrm{~L}$ ha $^{-1}+$ after 14 days $2 \mathrm{~L} \mathrm{ha}^{-1}$; 6) Kelpak $\mathrm{SL}$ at 4-leaf stage $3 \mathrm{~L} \mathrm{ha}^{-1}+$ after 14 days $2 \mathrm{~L} \mathrm{ha}^{-1}+$ after 28 days $2 \mathrm{~L} \mathrm{ha}^{-1} ; 7$ ) Kelpak SL at 4-leaf stage $2 \mathrm{~L} \mathrm{ha}^{-1}+$ after 14 days $2 \mathrm{~L} \mathrm{ha}^{-1}+$ after 28 days $2 \mathrm{~L} \mathrm{ha}^{-1}$; 8) Kelpak SL at 4-leaf stage $3 \mathrm{~L} \mathrm{ha}^{-1}+$ after 28 days $2 \mathrm{~L} \mathrm{ha}^{-1}$; 9) Kelpak SL at 4-leaf stage $2 \mathrm{~L} \mathrm{ha}^{-1}+$ after 28 days $2 \mathrm{~L}$ ha $^{-1 ;}$ 10) Asahi SL at 4-leaf stage $0.5 \mathrm{~L}$ $\mathrm{ha}^{-1}+$ after 14 days $0.5 \mathrm{~L} \mathrm{ha}^{-1}$. Kelpak SL and Asahi SL were applied in a form of foliar application. Biostimulants were diluted in water, 300 and $500 \mathrm{~L} \mathrm{ha}^{-1}$, respectively.

Pre-sowing fertilization was applied: $60 \mathrm{~kg} \mathrm{~N} \mathrm{ha}^{-1} ; 30.6 \mathrm{~kg} \mathrm{P} \mathrm{ha}^{-1} ; 66.4 \mathrm{~kg}$ $\mathrm{K} \mathrm{ha}^{-1}$. Seeds were sown in the first fortnight of April, with the sowing rate of $4 \mathrm{~kg} \mathrm{ha}^{-1}$, to a depth of $2 \mathrm{~cm}$, at the row spacing of $30 \mathrm{~cm}$. The treatments of plant protection from diseases and pests complied with carrot requirements.
The seeds were provided with Marshal $250 \mathrm{DS}$ seed dressing. After sowing and before plant emergence Afalon 450 SC herbicide was applied at the rate of 1.5 $\mathrm{L} \mathrm{ha}^{-1}$, while at the 3 -specific leaf phase Linurex $500 \mathrm{SC}$ was provided at the rate of $1.5 \mathrm{~L} \mathrm{ha}^{-1}$.

Plants were harvested at full physiological carrot maturity and samples were taken for storage (10 $\mathrm{kg}$ ) from each plot. The roots were then stored in chambers located in the Institute of Food Technology of the University of Sciences and Technology in Bydgoszcz. A constant temperature and relative air humidity were then maintained over six months of storage, according to the requirements of carrots. The carrot roots were stored at $+1{ }^{\circ} \mathrm{C}$ with $95 \%$ relative air humidity $(\mathrm{Rh})$.

The plant material was purified and roots were then cut into $1-\mathrm{cm}$-thick slices and freeze-dried (Christ Alpha 1-4 LSC, Germany) in order to achieve a permanent weight. Freeze-dried samples were then ground into flour using an electric grinder (Chemland, Type FW 177) and then used for chemical analysis. The obtained flour samples were then all stored in sealed plastic bags at $-20^{\circ} \mathrm{C}$ before analysis.

Carbohydrate analyses were made according to Talburt \& Smith (1987) procedures. For reducing sugar content assessment two grams of lyophilised sample was placed in $250 \mathrm{~mL}$ bottle, $150 \mathrm{~mL}$ distilled water was then added and shaken vigorously. One millilitre of the filtrate was mixed with $3 \mathrm{~mL}$ of DNP reagent in a test tube and then heated in a water bath at $95^{\circ} \mathrm{C}$ during 6 minutes. Absorbance of the mixture was measured using spectrophotometer at a wavelength of $600 \mathrm{~nm}$. The reducing sugar content was then estimated using the standard curve of glucose.

The total soluble carbohydrate was determined after hydrolysis of sugars. After filtration, $40 \mathrm{~mL}$ of the filtrate was taken, a few drops of concentrated $\mathrm{HCl}$ were added. The samples were 30 minutes warmed in a water bath. After cooling, the mixture was neutralized using a few drops of concentrated $\mathrm{NaOH}$. Next, $1 \mathrm{~mL}$ of the filtrate was mixed with $3 \mathrm{~mL}$ DNP reagent and proceeded according to the 
procedure for determining the content of reducing sugars. The saccharose content was calculated according to the formula (Sawicka \& Pszczółkowski, 2005): $\%$ saccharose $=(\%$ total sugars - \% reducing sugars) x 0.95 . Total carotenoids in carrot samples was extracted by procedures described by Herrero-Martinez et al. (2006). Eight grams of lyophilised carrot was blended with $100 \mathrm{~mL}$ saturated anhydrous sodium carbonate and mixed with a mechanical blender. Ten grams of the mixture was transferred into a centrifuge tube, added with $20 \mathrm{~mL}$ THF and mixed for 2 min under cold water. The mixture was centrifuged at $5000 \mathrm{~g}$ for $5 \mathrm{~min}$ and the supernatant was collected. Extraction was performed by adding $15 \mathrm{~mL} \mathrm{DCM}$ and $15 \mathrm{~mL}$ of $10 \% \mathrm{w} / \mathrm{v}$ $\mathrm{NaCl}$ into the supernatant and shaken for $2 \mathrm{~min}$. The extraction was repeated twice, organic layer was collected and evaporated under nitrogen steam. The residue was kept at $-20^{\circ} \mathrm{C}$, reconstituted with $5 \mathrm{~mL}$ DCM and diluted (1/40-fold) with DCM prior UV measurements (Shimadzu UV-1800, UV-Vis spectral photometer system Japan). Detection was performed at $450 \mathrm{~nm}$ according to PN-EN 12136:2000.

Standard $\beta$-carotene for identification was prepared in DCM to obtain 4 $\mu \mathrm{g} \mathrm{mL}^{-1}$. Ascorbic acid content was assessed according to Kapur et al. (2012). Then, five grams of sample of freeze-dried carrots were homogenized with $25 \mathrm{~mL}$ of metaphosphoric acidacetic acid solution, and quantitatively transferred into a $50 \mathrm{~mL}$ volumetric flask and shaken gently to homogenize solution. Then it was diluted up to the mark by the metaphosphoric acidacetic acid solution. The obtained solution was filtered and centrifuged at $4000 \mathrm{rpm}$ for 15 minutes, after what the supernatant solution was used for spectrophotometric determination (UV-1800, UV Spectrophotometer System, Japan) of ascorbic acid content in samples of different carrot roots. Procedure: $0.23 \mathrm{~mL}$ of $3 \%$ bromine water were added into $4 \mathrm{~mL}$ centrifuged sample solution to oxidize the ascorbic acid to dehydroascorbic acid and after that $0.13 \mathrm{~mL}$ of $10 \%$ thiourea to remove the excess of bromine. Then $1 \mathrm{~mL}$ of 2,4-DNPH solution was added to form osazone. All standards, samples and blank solution were kept at $37^{\circ} \mathrm{C}$ temperature for 3 hours in a thermostatic bath. After, all were cooled in ice bath for 30 minutes and treated with $5 \mathrm{~mL}$ chilled $85 \% \mathrm{H}_{2} \mathrm{SO}_{4}$, with constant stirring. As a result, a colored solution's absorbance was taken at $521 \mathrm{~nm}$.

The 3-year research results were statistically verified applying the analysis of variance method. The significance of differences was evaluated using Tukey multiple confidence intervals for the significance level $\alpha=0.05$. Analysis of variance of the data was computed using Statistica ${ }^{\circledR}$ 13.1. The coefficient of linear correlation value was calculated between the carrot quality characters investigated at $\mathrm{P}<0.05$ and $\mathrm{P}<0.01$.

\section{RESULTS AND DISCUSSION}

Of all the research years, 2011 was most favourable. The 2010 year was the less favourable for carrot growth and development with long-lasting drought in June, while 2009 with high precipitation, accompanied by low air temperature and long-lasting drought at the end of the vegetation period (AugustSeptember) was least favourable. The mean air temperatures were, in 2009 $14,5^{\circ} \mathrm{C}$; in $201014,7^{\circ} \mathrm{C}$ and in 2011 $15,2^{\circ} \mathrm{C}$. The total rainfall was $236.1 \mathrm{~mm}$, $477.3 \mathrm{~mm}$, and $386.9 \mathrm{~mm}$, in 2009, 2010 and 2011, respectively.

Carotenoids demonstrated a high antioxidant activity, which makes them one of the major of bioactive compounds occurring in carrot (Leong \& Oey, 2012). Cultivar Karotan demonstrated high content of total carotenoids after harvest, on average $115.4 \mathrm{mg} \mathrm{kg}^{-1}$ wet weight (Table 1). In the research carried out by Wszelaczyńska \& Pobereżny (2011), out of the five orange cultivars, Karotan contained the highest content of total carotenoids, amounting on average $136.1 \mathrm{mg} \mathrm{kg}^{-1}$ wet weight. Similar results were obtained by Sękara et al. (2012), where Karotan cultivar carotenoids content was $142.5 \mathrm{mg} \mathrm{kg}^{-1}$ wet weight. In our study the application of Kelpak SL and Asahi SL influenced an increase in the total carotenoid content in roots in comparison to the control. A significantly higher content of carotenoids was observed after a single

Table 1. Total carotenoids content in carrot roots depending on the biostimulant type and its application rate and frequency measured after harvest and after long-term storage, across study period. Bydgoszcz, University of Science and Technology, 2009-2011.

\begin{tabular}{lcccc}
\hline \multirow{2}{*}{$\begin{array}{l}\text { Biostimulant } \\
\text { type }[\mathbf{I I}]\left(\mathbf{L ~ h a}^{-1}\right)\end{array}$} & \multicolumn{3}{c}{$\begin{array}{c}\text { Carotenoids content [I] } \\
\text { (mg kg-1 FM) }\end{array}$} & $\begin{array}{c}\text { Deviation } \\
(\%)\end{array}$ \\
\cline { 2 - 4 } & $\begin{array}{c}\text { After } \\
\text { harvest }\end{array}$ & $\begin{array}{c}\text { After } \\
\text { storage }\end{array}$ & Average & \\
\hline Control & 110.4 & 110.1 & 110.3 & \\
Kelpak $(3) \dagger$ & 119.2 & 118.6 & 118.9 & +7.9 \\
Kelpak $(2)^{\dagger}$ & 121.1 & 120.5 & 120.8 & +9.6 \\
Kelpak $(3+2)^{\dagger}$ & 113.7 & 112.1 & 112.9 & +2.5 \\
Kelpak $(2+2)^{\dagger}$ & 111.9 & 111.8 & 111.9 & +1.4 \\
Kelpak $(3+2+2)^{\dagger}$ & 115.8 & 114.4 & 115.1 & +4.4 \\
Kelpak $(2+2+2)^{\dagger}$ & 116.8 & 116.5 & 116.7 & +5.8 \\
Kelpak $(3+2)^{\dagger}$ & 115.8 & 115.6 & 115.7 & +5.0 \\
Kelpak $(2+2)^{\ddagger}$ & 117.9 & 117.4 & 117.7 & +6.7 \\
Asahi $(0.5+0.5)^{\dagger}$ & 111.6 & 110.9 & 111.3 & +0.9 \\
\hline Total mean & 115.4 & 114.8 & 115.1 & \\
LSD $(0.05)$ & {$[\mathrm{I}]=0.32 ;[\mathrm{II}]=1.62 ;[\mathrm{I}] \times[\mathrm{II}]=\mathrm{NS}$} & \\
\hline
\end{tabular}

*Averaged across after harvest and after storage determination dates, control $=100 \%$. $\dagger$ One, two or three applications; where, second and third applied at 2-week interval. $\$$ One application at 4-leaf phase, followed with additional application after 4 weeks. \#NS= not significant. 
application of Kelpak SL. The best effect was obtained for the lowest dose, $2 \mathrm{~L} \mathrm{ha}^{-1}$, which can prove a significant role of this preparation for carotenoid synthesis (Table 1). A significant increase in the carotenoid content under the influence of biostimulant (Aminoplant) application was also obtained by Grabowska et al. (2012). Opposite results were obtained by Kwiatkowski et al. (2013), in whose study the application of biostimulants (Tytanit, Bio-algeen S 90 and Asahi SL) resulted in reduction of the total carotenoid content in carrot roots, although it was not statistically proved. It should be emphasized that, according to various authors (Leong \& Oey, 2012), genetic conditions, soil type or harvest time are of the highest importance for the carotenoid content in carrot and not the crop technology.

Carrot contains relatively low amounts of ascorbic acid, but due to its high bioactivity, it is considered a significant indicator of the nutritional value of its roots. Considering the high level of raw carrot consumption, carrot can provide an important source of vitamin $\mathrm{C}$ in the consumers' diet. In the conducted research, the average content of vitamin $\mathrm{C}$ in roots after harvest amounted to $87.3 \mathrm{mg} \mathrm{kg}^{-1}$ wet weight (Table 2). Its amount in roots depends on genetic conditions, although the effect of managed decisions cannot be excluded (Wszelaczyńska \& Pobereżny, 2011). Literature data reporting the content of this compound in carrot roots are divergent, and in one $\mathrm{kg}$ of wet weight of roots of orange cultivars can range from 25 to $117.9 \mathrm{mg}$ (Wszelaczyńska \& Pobereżny, 2011; Leong \& Oey, 2012). Our research indicated that the level of vitamin $\mathrm{C}$ significantly depended on the application of biostimulant. The application of Asahi SL did not affect the content of this compound, unlike the Kelpak preparation. In addition, the applied quantity and the date of its application were important. The significantly highest content of vitamin $\mathrm{C}$ at the level of $95.4 \mathrm{mg}$ $\mathrm{kg}^{-1}$ wet weight in relation to the content in roots originating from the control was obtained after a single application of Kelpak at the dose $2 \mathrm{~L}$ $\mathrm{ha}^{-1}$ (Table 2). The increased content obtained in relation to the control amounted to $19.1 \%$. Kwiatkowski et al. (2013), using Asahi SL, Bio-algeen S 90 and Tytanit biostimulants in carrot cultivation, obtained an increase in the

Table 2. Ascorbic acid content in carrot roots depending on the biostimulant type, and its application rate and frequency measured after harvest and after long-term storage, across study period. Bydgoszcz, University of Science and Technology, 2009-2011.

\begin{tabular}{|c|c|c|c|c|}
\hline \multirow{2}{*}{$\begin{array}{l}\text { Biostimulant }[\mathrm{II}] \\
\text { type (rate) }\left(\mathrm{L} \mathrm{ha} \mathbf{h a}^{-1}\right)\end{array}$} & \multicolumn{3}{|c|}{ Ascorbic acid content $[\mathrm{I}]\left(\mathrm{mg} \mathrm{kg}^{-1} \mathrm{FM}\right)$} & \multirow[b]{2}{*}{$\begin{array}{l}\text { Deviation } \\
(\%)^{*}\end{array}$} \\
\hline & $\begin{array}{c}\text { After } \\
\text { harvest }\end{array}$ & $\begin{array}{c}\text { After } \\
\text { storage }\end{array}$ & Average & \\
\hline Control & 80.1 & 59.6 & 69.9 & \\
\hline Kelpak $(3)^{\dagger}$ & 88.3 & 79.5 & 83.9 & +20.1 \\
\hline Kelpak $(2)^{\dagger}$ & 95.4 & 80.5 & 88.0 & +25.9 \\
\hline Kelpak $(3+2)^{\dagger}$ & 85.6 & 70.7 & 78.2 & +11.9 \\
\hline Kelpak $(2+2)^{\dagger}$ & 82.3 & 68.6 & 75.4 & +8.0 \\
\hline Kelpak $(3+2+2)^{\dagger}$ & 87.8 & 71.8 & 79.8 & +14.3 \\
\hline Kelpak $(2+2+2)^{\dagger}$ & 90.6 & 77.4 & 84.0 & +20.3 \\
\hline Kelpak $(3+2)^{\ddagger}$ & 89.9 & 74.9 & 82.4 & +18.0 \\
\hline Kelpak $(2+2)^{\ddagger}$ & 91.7 & 79.2 & 85.4 & +22.3 \\
\hline Asahi $(0.5+0.5)^{\dagger}$ & 81.0 & 64.0 & 72.5 & +3.7 \\
\hline Total mean & 87.3 & 72.6 & 80.0 & \\
\hline $\operatorname{LSD}(0.05)$ & \multicolumn{4}{|c|}{$[\mathrm{I}]=3.96 ;[\mathrm{II}]=4.79 ;[\mathrm{I}] \times[\mathrm{II}]=5.97$} \\
\hline
\end{tabular}

*Averaged across after harvest and after storage determination dates, control $=100 \%$. ${ }^{\dagger}$ One, two or three applications; where, second and third applied at 2-week interval. ${ }^{*}$ One application at 4-leaf phase, followed with additional application after 4 weeks. ${ }^{*} \mathrm{NS}=$ not significant.
L-ascorbic acid content in relation to the control object by: $12.2 \%, 15.1 \%$ and $8.7 \%$, respectively. It is commonly believed that the application of growth stimulants can be beneficial in terms of the nutrient content only in those cases when the treated plants are cultivated in unfavourable conditions (poorer soil, worse forecrop, a reduced dose of mineral fertilizing) (Kwiatkowski \& Juszczak, 2011). The results obtained in our own research did not confirm such a relation. They are consistent with the results by Przybysz et al. (2010), which clearly indicated that the application of biostimulants can be also effective and efficient when the vegetables are cultivated under optimum conditions.

The average content of total and reducing sugars was 74.6 and $20.0 \mathrm{~g}$ $\mathrm{kg}^{-1}$ wet weight, respectively (Tables 3 and 5). Sugar content in carrot roots intended for fresh market is an indicator of its quality, both in terms of energy and sensory values. A sweet taste of carrot, contributing to the total palatability of roots, is primarily determined by its sugar content (Kiraci \& Padem, 2016). Sękara et al. (2012), examining 10 carrot cultivars, obtained the total content of sugars at the average level of $53.5 \mathrm{~g} \mathrm{~kg}^{-1}$ wet weight, and the Karotan cultivar contained $58.4 \mathrm{~g} \mathrm{~kg}^{-1}$ sugars in wet weight. In the research carried out by Leong \& Oey (2012), and Kiraci \& Padem (2016), regardless of genetic conditions, the total concentration of the sugar content in carrot roots ranged from 50 to $83 \mathrm{~g} \mathrm{~kg}^{-1}$ wet weight. On the other hand, Sharma et al. (2012) obtained lower content of total sugars in carrot roots $\left(27-45 \mathrm{~g} \mathrm{~kg}^{-1}\right)$. In this research, the contents of total sugar, saccharose and reducing sugars (Tables 3-5) were the lowest in roots originated from the control (without biostimulant application) and each type and dose of a biostimulant resulted in a significant increase in their concentration. We observed that the application of Asahi SL and Kelpak SL in two doses in the initial period of carrot vegetation resulted in an increase in total sugars, yet it was not statistically proven. On the other hand, the application of Kelpak SL, in a single, lowest dose $\left(2 \mathrm{~L} \mathrm{ha}^{-1}\right)$ at 4-leaf development phase 
resulted in the highest significant increase of total sugars by $5.0 \%$, and reducing sugars by $12.2 \%$ (Tables 3,5 ) which is consistent with the research conducted by Grabowska et al. (2012).
The authors found that carrot roots from the object where aminoplant biostimulant was foliar applied in a single dose of $3.0 \mathrm{Lha}^{-1}$ contained significantly more sugars. On the other

Table 3. Total sugar content in carrot roots depending on the biostimulant type, and its application rate and frequency measured after harvest and after long-term storage, across study period. Bydgoszcz, University of Science and Technology, 2009-2011.

\begin{tabular}{|c|c|c|c|c|}
\hline \multirow{2}{*}{$\begin{array}{l}\text { Biostimulant } \\
\text { [II] type (rate) } \\
\text { (L ha-1) }\end{array}$} & \multicolumn{3}{|c|}{ Total sugar content $[\mathrm{I}]\left(\mathrm{g} \mathrm{kg}^{-1} \mathrm{FM}\right)$} & \multirow{2}{*}{$\begin{array}{c}\text { Deviation } \\
(\%)^{*}\end{array}$} \\
\hline & $\begin{array}{c}\text { After } \\
\text { harvest }\end{array}$ & $\begin{array}{c}\text { After } \\
\text { storage }\end{array}$ & Average & \\
\hline Control & 72.5 & 69.2 & 70.9 & \\
\hline Kelpak $(3)^{\dagger}$ & 75.8 & 72.0 & 73.9 & +4.26 \\
\hline Kelpak $(2)^{\dagger}$ & 76.1 & 72.1 & 74.1 & +4.58 \\
\hline Kelpak $(3+2)^{\dagger}$ & 73.7 & 70.1 & 71.9 & +1.51 \\
\hline Kelpak $(2+2)^{\dagger}$ & 73.6 & 70.0 & 71.8 & +1.27 \\
\hline Kelpak $(3+2+2)^{\dagger}$ & 73.9 & 70.3 & 72.1 & +1.75 \\
\hline Kelpak $(2+2+2)^{\dagger}$ & 75.3 & 71.1 & 73.2 & +3.32 \\
\hline Kelpak $(3+2)^{\ddagger}$ & 74.6 & 70.8 & 72.7 & +2.64 \\
\hline Kelpak $(2+2)^{*}$ & 75.5 & 71.7 & 73.6 & +3.92 \\
\hline Asahi $(0.5+0.5)^{\dagger}$ & 72.9 & 69.7 & 71.3 & +0.58 \\
\hline
\end{tabular}

\begin{tabular}{lccc}
\hline Total mean & 74.6 & 70.9 & 72.5 \\
$\operatorname{LSD}(0.05)$ & {$[\mathrm{I}]=2.15 ;[\mathrm{II}]=1.18 ;[\mathrm{I}] \times[\mathrm{II}]=\mathrm{NS}^{\#}$} \\
\hline
\end{tabular}

*Averaged across after harvest and after storage determination dates, control $=100 \%$. $\uparrow$ One, two or three applications; where, second and third applied at 2-week interval. $\$$ One application at 4-leaf phase, followed with additional application after 4 weeks. \#NS= not significant.

Table 4. Saccharose content in carrot roots depending on the biostimulant type, and its application rate and frequency measured after harvest and after long-term storage, across study period. Bydgoszcz, University of Science and Technology, 2009-2011.

\begin{tabular}{|c|c|c|c|c|}
\hline \multirow{2}{*}{$\begin{array}{l}\text { Biostimulant } \\
\text { [II] type (rate) } \\
\text { (L ha-1) }\end{array}$} & \multicolumn{3}{|c|}{ Saccharose content $[\mathrm{I}]\left(\mathrm{g} \mathrm{kg}^{-1} \mathrm{FM}\right)$} & \multirow{2}{*}{$\begin{array}{c}\text { Deviation } \\
(\%)^{*}\end{array}$} \\
\hline & $\begin{array}{c}\text { After } \\
\text { harvest }\end{array}$ & $\begin{array}{c}\text { After } \\
\text { storage }\end{array}$ & Average & \\
\hline Control & 51.0 & 47.3 & 49.2 & \\
\hline Kelpak $(3)^{\dagger}$ & 52.1 & 47.5 & 49.8 & +1.19 \\
\hline Kelpak $(2)^{\dagger}$ & 52.2 & 47.4 & 49.8 & +1.24 \\
\hline Kelpak $(3+2)^{\dagger}$ & 51.5 & 47.2 & 49.4 & +0.37 \\
\hline $\operatorname{Kelpak}(2+2)^{\dagger}$ & 51.6 & 47.6 & 49.6 & +0.75 \\
\hline Kelpak $(3+2+2)^{\dagger}$ & 51.6 & 47.0 & 49.3 & +0.15 \\
\hline Kelpak $(2+2+2)^{\dagger}$ & 52.2 & 47.1 & 49.7 & +0.86 \\
\hline Kelpak $(3+2)^{\ddagger}$ & 51.8 & 47.3 & 49.6 & +0.75 \\
\hline Kelpak $(2+2)^{\ddagger}$ & 52.0 & 47.6 & 49.8 & +1.28 \\
\hline Asahi $(0.5+0.5)^{\dagger}$ & 51.2 & 47.4 & 49.3 & +0.22 \\
\hline Total mean & 51.9 & 47.5 & 49.7 & \\
\hline $\operatorname{LSD}(0.05)$ & \multicolumn{4}{|c|}{$[\mathrm{I}]=2.77 ;[\mathrm{II}]=\mathrm{NS}^{\#} ;[\mathrm{I}] \times[\mathrm{II}]=\mathrm{NS}^{\#}$} \\
\hline
\end{tabular}

*Averaged across after harvest and after storage determination dates, control $=100 \%$. ${ }^{\dagger}$ One, two or three applications; where, second and third applied at 2-week interval. ${ }^{\star}$ One application at 4-leaf phase, followed with additional application after 4 weeks. ${ }^{*} \mathrm{NS}=$ not significant.

hand, studies by Kwiatkowski et al. (2013), indicated that carrot roots from the control object had a significantly lower content of total sugars than carrot roots fertilized with biostimulants. Among the biostimulating preparations applied by the authors, Tytanit had the most favourable effect on the total sugar content (19.9\% average growth), followed by Bio-algeen S 90 (8.1\% growth) and Asahi SL (6.8\% growth).

Sugar content in carrots during the vegetation period demonstrates a strong growing tendency along with root maturity. The highest concentration of sugars obtained in our research at the initial period of carrot vegetation could result from the exogenous effect of phytohormones in the Kelpak SL biostimulant. It has been demonstrated that phytohormones can accelerate the transport of electrons in the photosynthesis process, and consequently more assimilates are created as reserve material (Kwiatkowski et al., 2013). The research by Smoleń \& Sady (2009) demonstrated that foliar application in carrots cultivar Kazan F1, with Pentakeep V biostimulant contributed to reducing sugar content, although it contains natural, non-protein aminoacid-5-aminolevulinic acid (ALA), which is chlorophyll precursor in the plant (Memon et al., 2009), which can increase photosynthesis efficiency and improve quality parameters of yield (Yaronskaya et al., 2006). Such results could be the consequence of unfavourable temperature and humidity conditions during the vegetation, since the results of other studies demonstrated a positive effect on the yield quality (Seljasen et al., 2012).

Our research demonstrated losses after storing carrot roots during six months in the content of carotenoids, total sugars, saccharose and ascorbic acid, amounting to, respectively: 0.5 ; $5.0 ; 8.5$ and $16.8 \%$ (Tables $1-4$ ). On the other hand, a $4.5 \%$ increase in monosaccharides was observed, which directly results from the decomposition of polysaccharides during the carrot root storage (Table 5). The initial quality of carrot roots observed directly after harvest can be subject to changes during storage (Gajewski et al., 2010; 
Wszelaczyńska \& Pobereżny, 2011). This is confirmed by the results of research carried out in other experiments (Wszelaczyńska \& Pobereżny, 2011). Opposite results were obtained by
Kidmose et al. (2004) in a study where an increase in carotenoids after root storage was slow, and by Gajewski et al. (2010), who obtained an increase at the level of $19.2 \%$. Carotenoid

Table 5. Monosaccharides content in carrot roots depending on the biostimulant type, and its application rate and frequency measured after harvest and after long-term storage, across study period. Bydgoszcz, University of Science and Technology, 2009-2011.

\begin{tabular}{|c|c|c|c|c|}
\hline \multirow{2}{*}{$\begin{array}{l}\text { Biostimulant } \\
\text { [II] type (rate) } \\
\text { (L ha-1) }\end{array}$} & \multicolumn{3}{|c|}{ Monosacharides content $[\mathrm{I}]\left(\mathrm{g} \mathrm{kg}^{-1} \mathrm{FM}\right)$} & \multirow{2}{*}{$\begin{array}{c}\text { Deviation } \\
(\%)^{*}\end{array}$} \\
\hline & $\begin{array}{c}\text { After } \\
\text { harvest }\end{array}$ & $\begin{array}{c}\text { After } \\
\text { storage }\end{array}$ & Average & \\
\hline Control & 18.9 & 19.3 & 19.1 & \\
\hline Kelpak $(3)^{\dagger}$ & 21.0 & 22.0 & 21.5 & +14.08 \\
\hline Kelpak $(2)^{\dagger}$ & 21.2 & 22.2 & 21.7 & +15.07 \\
\hline Kelpak $(3+2)^{\dagger}$ & 19.5 & 20.4 & 20.0 & +5.79 \\
\hline $\operatorname{Kelpak}(2+2)^{\dagger}$ & 19.3 & 19.9 & 19.6 & +2.89 \\
\hline Kelpak $(3+2+2)^{\dagger}$ & 19.8 & 20.7 & 20.3 & +7.47 \\
\hline Kelpak $(2+2+2)^{\dagger}$ & 20.4 & 21.6 & 21.0 & +11.66 \\
\hline Kelpak $(3+2)^{\ddagger}$ & 20.1 & 21.1 & 20.6 & +9.15 \\
\hline Kelpak $(2+2)^{\ddagger}$ & 20.8 & 21.6 & 21.2 & +12.05 \\
\hline Asahi $(0.5+0.5)^{\dagger}$ & 19.0 & 19.8 & 19.4 & +2.37 \\
\hline Total mean & 20.0 & 20.9 & 20.4 & \\
\hline $\operatorname{LSD}(0.05)$ & \multicolumn{4}{|c|}{$[\mathrm{I}]=\mathrm{NS}^{\#} ;[\mathrm{II}]=0.53 ;[\mathrm{I}] \times[\mathrm{II}]=\mathrm{NS}^{\#}$} \\
\hline
\end{tabular}

*Averaged across after harvest and after storage determination dates, control $=100 \%$. ${ }^{\dagger}$ One, two or three applications; where, second and third applied at 2-week interval. ${ }^{*}$ One application at 4-leaf phase, followed with additional application after 4 weeks. " $\mathrm{NS}=$ not significant.

Table 6. Daily nutrients consumption for the consumption of $55 \mathrm{~g}$ of carrot*. Bydgoszcz, University of Science and Technology, 2009-2011.

\begin{tabular}{lccccc}
\hline \multirow{2}{*}{$\begin{array}{l}\text { Biostimulant type } \\
\text { (rate) }\left(\mathbf{L} \text { ha }^{-1}\right)\end{array}$} & \multicolumn{4}{c}{ Consumption $\left(\right.$ mg day $\left.^{-1}\right)$} \\
\cline { 2 - 3 } \cline { 5 - 6 } \cline { 5 - 6 } & $\begin{array}{c}\text { Cfter } \\
\text { harvest }\end{array}$ & $\begin{array}{c}\text { After } \\
\text { storage }\end{array}$ & & $\begin{array}{c}\text { After } \\
\text { harvest }\end{array}$ & $\begin{array}{c}\text { After } \\
\text { storage }\end{array}$ \\
\hline Control & 6.07 & 6.05 & & 4.41 & 3.28 \\
Kelpak $(3) \dagger$ & 6.56 & 6.52 & & 4.85 & 4.37 \\
Kelpak $(2) \dagger$ & 6.66 & 6.63 & & 5.25 & 4.43 \\
Kelpak $(3+2) \dagger$ & 6.25 & 6.17 & & 4.71 & 3.89 \\
Kelpak $(2+2) \dagger$ & 6.15 & 6.15 & & 4.53 & 3.77 \\
Kelpak $(3+2+2) \dagger$ & 6.37 & 6.29 & & 4.83 & 3.95 \\
Kelpak $(2+2+2) \dagger$ & 6.42 & 6.41 & & 4.98 & 4.26 \\
Kelpak $(3+2) \dagger$ & 6.37 & 6.36 & & 4.94 & 4.12 \\
Kelpak $(2+2) \dagger$ & 6.48 & 6.46 & & 5.04 & 4.36 \\
Asahi $(0.5+0.5) \dagger$ & 6.14 & 6.10 & & 4.45 & 3.52 \\
\hline Total mean & 6.35 & 6.31 & & 4.80 & 4.00 \\
\hline
\end{tabular}

$\dagger$ One, two or three applications; where, second and third applied at 2-week interval. $\$$ One application at 4-leaf phase, followed with additional application after 4 weeks. *Consumption of fresh and processed carrot (without juice) is $20 \mathrm{~kg}$ year-1 per person in Poland. RDA (recommended dietary allowances): Vitamin $\mathrm{A}=0.9 \mathrm{mg}$ day-1; Vitamin $\mathrm{C}=90 \mathrm{mg}$ day- 1 . dyes belong to stable compounds and, during storage, a minor change in their content can take place (Sękara et al., 2012). Sugar compounds are reserve substances, which are used during storage in the plant tissue respiration process. Consequently, after storage, a decrease in their content occurs (Gajewski et al., 2010; Wszelaczyńska \& Pobereżny, 2011). However, it is vitamin $C$ that belongs to the most unstable nutrients during the plant material storage (Seljasen et al., 2012; Wszelaczyńska \& Pobereżny, 2011).

The correlation analysis after harvest indicated a strong relation (a critical value of the correlation coefficient at the level of 0.01) between the content of the examined component in carrot roots. It was demonstrated that the correlation between total sugar and reducing sugar content and the content of carotenoids or ascorbic acid was higher for carotenoids. Correlation coefficients, after harvest, between carotenoids present in carrot roots and total and reducing sugars were $r=0.948$ and 0.939 , respectively. Similar relations were obtained after storage. A close relationship at the level of $\mathrm{P}<0.05$ between the total content of $\beta$-carotene and the total sugar content $(\mathrm{r}=0.70)$ was also confirmed in the research by Kiraci $\&$ Padem (2016).

Carotenoids and vitamin $\mathrm{C}$, which control antioxidative mechanisms in the human body, are important nutritional components. According to various sources, vegetable consumption should amount to about $500 \mathrm{~g}$ in 4-5 meals a day. Since carrot belongs to the group of most frequently consumed vegetables, daily intake of total carotenoids and vitamin $\mathrm{C}$ was determined, assuming the consumption of $55 \mathrm{~g}$ of the examined carrot per person (Table 6). Comparing the data obtained with the norms specifying the recommended dietary allowances (RDA), consumption of 55 $\mathrm{g}$ of the examined carrot provides a low coverage of daily demand for vitamin C. On the other hand, a significant daily intake of carotenoids can be observed. Converting the obtained total carotenoid content into vitamin $\mathrm{A}$, assuming $18 \mathrm{mg}$ carotenoids as $1 \mathrm{mg}$ retinol equivalent (RE), consumption of $55 \mathrm{~g}$ carrot provides, on average, $39.1 \%$ of the daily 
demand for vitamin A.

Kelpak biostimulant had an effect on the content of total sugars and monosaccharides, carotenoids and L-ascorbic acids in carrot of the Karotan cultivar. The most favourable effect on the nutritional value of carrot was found for Kelpak applied in a single dose of 2 $\mathrm{L} \mathrm{ha}^{-1}$. Carrot analysis after six months of storage revealed a decrease in the nutrient content in the roots. Regardless of the experimental factors, the amount of carotenoids increased in carrot roots along with the growth of the total sugars and monosaccharide content.

\section{REFERENCES}

ALAM, MZ; BRAUN, G; NORRIE, J; HODGES, DM. 2014. Ascophyllum extract application can promote plant growth and root yield in carrot associated with increased rootzone soil microbial activity. Canadian Journal of Plant Science 94: 337-348.

CZECZKO, R; MIKOS-BIELAK, M. 2004. Effects of Asahi bio-stimulator application in the cultivation of different vegetable species. Annales UMCS, sec. E Agricultura 59: 10731079.

G A J E W S K I, M; S Z Y M C Z A K, P; DANILCENKO, H. 2010. Changes of physical and chemical traits of roots of different carrot cultivars under cold store conditions. Vegetable Crops Research Bulletin 72: 115-127.

GRABOWSKA, A; KUNICKI, E; SĘKARA, A; KALISZ, A. 2012. The effect of cultivar and biostimulant treatment on the carrot yield and its quality. Vegetable Crops Research Bulletin 77: 37-48.

HERRERO-MARTÍNEZ, JM; EELTINK, S; SCHOENMAKERS, PJ; KOK, WT; RAMIS-RAMOS, G. 2006. Determination of major carotenoids in vegetables by capillary electrochromatography. Journal of Separation Science 29: 660-665.
KAPUR, A; HASKOVIĆ, A; ČOPRAJANIĆIJEVIĆ, A; KLEPO, L; TOPČAGIĆ, A; TAHIROVIĆ, I; SOFIĆ, E. 2012. Spectrophotometric analysis of total ascorbic acid content in various fruits and vegetables. Bulletin of the Chemists and Technologists of Bosnia and Herzegovina 38: 39-42.

KIDMOSE, U; HANSEN, SL; CHRISTENSEN, LP; EDELENBOS, M; LARSEN, E; NØRBÆK, R. 2004. Effects of genotype, root size, storage, and processing on bioactive compounds in organically grown carrots (Daucus carota L.). Journal of Food Science 69: 388-394.

KIRACI, S; PADEM, H. 2016. Determination of the chemical and sensory characteristics of some carrot varieties grown in Turkey. Acta Scientiarum Polonorum Hortorum Cultus 15: 139-147.

KOCIRA, S; SZPARAGA, A; KOCIRA, A; CZERWIŃSKA, E; WÓJTOWICZ, A; BRONOWICKA-MIELNICZUK, U; KOSZEL, M; FINDURA, P. 2018. Modeling biometric traits, yield and nutritional and antioxidant properties of seeds of three soybean cultivars through the application of biostimulant containing seaweed and amino acids. Frontiers in Plant Science 9: 388.

KWIATKOWSKI, C; JUSZCZAK, J. 2011. The response of sweet basil (Ocimum basilicum L.) to the application of growth stimulators and forecrops. Acta Agrobotanica 64: 69-76.

KWIATKOWSKI, CA; KOŁODZIEJ, B; WOŹNIAK, A. 2013. Yield and quality parameters of carrot (Daucus carota L.) roots depending on growth stimulators and stubble crops. Acta Scientiarum Polonorum Hortorum Cultus 12: 55-68.

LEONG, SY; OEY, I. 2012. Effect of processing on anthocyanius, carothenoids and vitamin $\mathrm{C}$ in summer fruits and vegetables. Food Chemistry 133: 1577-1587.

MEMON, SA; HOU, X; WANG, L; LI, Y. 2009. Promotive effect of 5-aminolevulinic acid on chlorophyll, antioxidative enzymes and photosynthesis of Pakchoi (Brassica campestris ssp. chinensisvar. communis 'Tsen et Lee'). Acta Physiologiae Plantarum 31: 51-57.

PRZYBYSZ,A; WROCHNA, M; SŁOWIŃSKI, A; GAWROŃSKA, H. 2010. Stimulatory effect of Asahi SL on selected plant species.
Acta Scientiarum PolonorumHortorum Cultus 9: 53-64.

SAWICKA, B; PSZCZÓŁKOWSKI, P. 2005. Dry matter and carbohydrates content in the tubers of very early potato varieties cultivated under coverage. Acta Scientiarum Polonorum Hortorum Cultus 4: 111-122.

SĘKARA, A; KALISZ, A; CEBULA, S; GRABOWSKA, A. 2012. The quality and processing usefulness of chosen Polish carrot cultivars. Acta Scientiarum Polonorum Hortorum Cultus 11: 101-112.

SELJASEN, R; LEA, P; TORP, T; RILEY, $\mathrm{H}$; BERENTSEN, E; THOMSEND, M; BENGTSSONB, GB. 2012. Effects of genotype, soil type, year and fertilisation on sensory and morphological attributes of carrots (Daucus carota L.). Journal of the Science of Food and Agriculture 92: 1786-1799.

SHARMA, KD; KARKI, S; THAKUR, NS; ATTRI, S. 2012. Chemical composition, functional properties and processing of carrot - a review. Journal of Food Science and Technology 49: 22-32.

SMOLEŃ, S; SADY, W. 2009. The effect of nitrogen fertilizer form and foliar application on the concentrations of twenty-five elements in carrot. Folia Horticulturae 21: 3-16.

SZCZEPANEK, M.; SIWIK-ZIOMEK, A. 2019. $P$ and $K$ accumulation by rapeseed as affected by biostimulant under different NPK and S fertilization doses. Agronomy 9: 477.

SZCZEPANEK, M; WSZELACZYŃSKA, E; POBEREŻNY, J; OCHMIAN I. 2017. Response of onion (Allium cepa L.) to the method of seaweed biostimulant application Acta Scientiarum Polonorum Hortorum Cultus 16: $113-122$.

TALBURT, WF; SMITH, O. 1987. Potato processing. Van Nostrand Reinhold Co., New York: 371-474.

WSZELACZYŃSKA, E; POBEREŻNY, J. 2011. Effect of foliar magnesium fertilisation and storage on some parameters of the nutritive value of carrot storage roots. Journal of Elementology 16: 635-649.

YARONSKAYA, E; VERSHILOVSKAYA, I; POERS, Y; ALAWADY, AE; AVERINA, N; GRIMM, B. 2006. Cytokinin effects on tetrapyrrole biosynthesis and photosynthetic activity in barley seedlings. Planta 224: 700-709. 